\title{
Campylobacter like organisms and reflux gastritis
}

\author{
HJ O'CONNOR,* JI WYATT, $\dagger$ MF DIXON, $\dagger$ ATR AXON* \\ From the ${ }^{*}$ Gastroenterology Unit and University Department of $\uparrow$ Pathology, General Infirmary at Leeds
}

SUMMARY A total of 98 patients, who had undergone gastric surgery (23), or who had peptic ulcers (56), or who had normal endoscopic findings (19) underwent gastric biopsy, together with measurement of $\mathrm{pH}$ and total bile acid concentration, in their fasting gastric juice. The biopsy specimens were stained by the Warthin-Starry method for Campylobacter like organisms and were also graded "blind," as described in the preceding paper, for the five features that we believe may constitute the histological picture of reflux gastritis. The individual grades were added together to give a composite "reflux score" (0-15) for each patient. We found a notable association between the absence of Campylobacter like organisms and previous surgery for peptic ulceration, high reflux scores $(>10)$, hypochlorhydria $(\mathrm{pH} \geqslant 4)$, and increased bile acid concentrations $(\geqslant 1 \mathrm{mmol} / \mathrm{l})$ in the stomach.

These findings further support our contention that reflux gastritis represents a distinct histopathological entity causally related to the effects of enterogastric reflux on the gastric mucosa and suggest that there may be two major categories of chronic gastritis: chronic superficial, or atrophic gastritis related to Campylobacter like organisms and reflux gastritis. Our data also imply that patients with peptic ulceration may, after gastric surgery, revert from being positive for these organisms to being negative and may undergo a possible transition from Campylobacter related chronic gastritis to reflux gastritis.

The consistent finding of Campylobacter like organisms in antral gastric biopsy specimens showing non-specific (type B) chronic gastritis ${ }^{1-7}$ has led to a reconsideration of existing views on the aetiology of this condition. Based on an experiment that entailed the self administration of a culture of Campylobacter pyloridis, Marshall et al suggested that chronic gastritis results from a failure to clear Campylobacter organisms after an initial acute infective gastritis. ${ }^{8}$

In the preceding paper ${ }^{9}$ we described a constellation of histological features, which we believe to be associated with reflux of alkaline duodenal content into the stomach. If reflux gastritis is truly a separate clinicopathological entity with a distinctive histological picture a radically different pattern of association with Campylobacter like organisms to that found in "conventional" chronic gastritis might be expected.

To explore this hypothesis we compared the histological findings, especially those we consider to be indicative of reflux, with the presence or absence of Campylobacter like organisms in the same biopsy series. Additionally, we used the $\mathrm{pH}$ and bile acid

Accepted for publication 8 January 1986 concentrations in fasting gastric juice as measures of alkaline refiux and related these to Campylobacter like organism status.

\section{Methods}

Ninety eight patients were included in this study (Table 1). As before ${ }^{9}$ they were drawn from five clinical groups, normal findings at endoscopy $(n=19)$, . active benign gastric ulceration $(n=25)$, duodenal ulceration $(n=16)$, combined duodenal and gastric ulceration $(n=15)$, and a group of postoperative patients $(n=23)$.

Fasting gastric juice was aspirated at endoscopy, and four biopsy specimens were taken from within $5 \mathrm{~cm}$ of pylorus or the stoma in the operated group.

The routine sections stained with haematoxylin and eosin and with periodic acid Schiff and alcian Blue, pH 2.5, were examined by MFD, who was unaware of the endoscopic findings, gastric $\mathrm{pH}$, or bile acid concentrations. The following histological features were assessed and given a score of $0-3$ equivalent to normal or absent (0), mild (1), moderate (2), and severe abnormality or severe increase (3); foveolar hyperplasia; lamina propria oedema; vasodilatation and 
Table 1 Details of patients and their Campylobacter status

\begin{tabular}{|c|c|c|c|c|c|c|}
\hline \multirow[t]{2}{*}{ Group } & \multirow{2}{*}{$\begin{array}{l}\text { No of } \\
\text { patients }\end{array}$} & \multicolumn{2}{|c|}{ Sex } & \multicolumn{2}{|c|}{ Age (year) } & \multirow[t]{2}{*}{ No positive } \\
\hline & & $\boldsymbol{M}$ & $\boldsymbol{F}$ & Mean & Range & \\
\hline $\begin{array}{l}\text { Normal endoscopy } \\
\text { Duodenal ulceration } \\
\text { Gastric ulceration } \\
\text { Combined duodenal and }\end{array}$ & $\begin{array}{l}19 \\
16 \\
25\end{array}$ & $\begin{array}{r}10 \\
9 \\
12\end{array}$ & $\begin{array}{r}9 \\
7 \\
13\end{array}$ & $\begin{array}{l}41 \cdot 7 \\
44 \cdot 4 \\
62 \cdot 9\end{array}$ & $\begin{array}{l}22-75 \\
21-76 \\
36-83\end{array}$ & $\begin{array}{l}12 \\
14 \\
20\end{array}$ \\
\hline $\begin{array}{l}\text { gastric ulceration } \\
\text { Postoperative }\end{array}$ & $\begin{array}{l}15 \\
23\end{array}$ & $\begin{array}{r}6 \\
19\end{array}$ & $\begin{array}{l}9 \\
4\end{array}$ & $\begin{array}{l}54 \cdot 5 \\
56 \cdot 9\end{array}$ & $\begin{array}{l}37-77 \\
26-78\end{array}$ & $\begin{array}{r}12 \\
6\end{array}$ \\
\hline
\end{tabular}

congestion; neutrophil polymorph infiltration; chronic inflammatory cell infiltration; intestinal metaplasia.

To calculate a composite reflux gastritis score the scores for acute and chronic inflammatory cells were modified to reflect their paucity-that is, a severe increase became 0 , moderate increase 1 , minor increase 2, and normal numbers of chronic inflammatory cells and absence of polymorphs 3 . These modified scores were added to the scores given to the first three variables listed yielding a reflux gastritis score in the range $0-15$.

A further section was taken from each set of biopsies and stained by the Warthin-Starry method for Campylobacter like organisms. These sections were examined by JIW, who was unaware of the findings in the routinely stained sections and the other investigations. The presence of Campylobacter like organisms in any of the biopsy specimens was recorded. Bile acid concentrations and $\mathrm{pH}$ were measured according to previous methods. ${ }^{9}$

Differences between the groups positive and negative for Campylobacter like organisms in reflux gastritis scores, gastric $\mathrm{pH}$, and bile acid concentrations were tested for significance by $\chi^{2}$ analysis and the Mann-Whitney U test.

\section{Results}

Campylobacter like organisms were detected in 64 of the 98 patients (65\%): Table 1 shows the distribution of the positive cases. Considerably fewer postoperative patients (six of 23) were positive compared with patients in the other clinical groups studied. Of the negative cases, three (one normal endoscopy, one duodenal ulceration, and one postoperative) were considered to have normal histological findings, and these patients were eliminated from subsequent analysis.

\section{REFLUX GASTRITIS SCORES AND}

CAMPYLOBACTER LIKE ORGANISM STATUS

When the distribution of Campylobacter positive and negative cases was tabulated with regard to reflux gastritis scores (Table 2), there was a highly significant difference in distribution between patients with higher $(>10)$ and lower $(\leqslant 10)$ reflux scores. Of the 31 patients who were negative, 24 had a score $>10 \mathrm{com}$ pared with only 12 of 64 in the positive group. Reflux gastritis scores (mean (SD)) were also significantly higher in the negative group (11.7 (2.3)) compared with those of the positive group (8.2 (2.5)) $(p=$ 0.0004).

Contingency tables were constructed for individual histological variables thought to be related to Campylobacter like organism status (Table 2), and these showed highly significant associations between increased neutrophil polymorphs and increased chronic inflammatory cells, and Campylobacter like organism positivity. To exclude the possibility that observed differences in reflux gastritis scores between the negative and positive groups might be accounted for solely on the basis of differences in the intensity of the inflammatory cell infiltrate a modified reflux score was calculated for each patient by adding the scores allotted for foveolar hyperplasia, lamina propria oedema, and vasodilatation and congestion. This

Table 2 Histological grades and Campylobacter like organism status

\begin{tabular}{|c|c|c|c|c|c|c|c|c|c|}
\hline & \multirow[t]{2}{*}{$\begin{array}{l}\text { No of } \\
\text { patients }\end{array}$} & \multicolumn{2}{|c|}{ Reflux gastritis score } & \multicolumn{2}{|c|}{ Increased polymorphs } & \multicolumn{2}{|c|}{$\begin{array}{l}\text { Increased chronic } \\
\text { inflammatory cells }\end{array}$} & \multicolumn{2}{|c|}{ Intestinal metaplasia $\frac{\mathrm{C}}{\overparen{D}}$} \\
\hline & & $\leqslant 10$ & $>10$ & Normal & Mild to severe & Normal & Mild to severe & Normal & Mild to severy \\
\hline $\begin{array}{l}\text { Campylob } \\
\text { Negative } \\
\text { Positive } \\
\text { Total }\end{array}$ & $\begin{array}{l}\text { acter like o } \\
31 \\
64 \\
95\end{array}$ & $\begin{array}{c}\text { ganisms } \\
7 \\
52\end{array}$ & $\left.\begin{array}{l}24 \\
12\end{array}\right\} \begin{array}{l}\chi^{2}=30.545 \\
\mathrm{p}<0.0001\end{array}$ & $\begin{array}{r}18 \\
6\end{array}$ & $\left.\begin{array}{l}13 \\
58\end{array}\right\} \begin{array}{l}\chi^{2}=26 \cdot 222 \\
\mathrm{p}<0.0001\end{array}$ & $\begin{array}{r}16 \\
2\end{array}$ & $\left.\begin{array}{l}15 \\
62\end{array}\right\} \begin{array}{l}x^{2}=31.972 \\
\mathrm{p}<0.0001\end{array}$ & $\begin{array}{l}20 \\
41\end{array}$ & $\left.\begin{array}{l}11 \\
23\end{array}\right\} \begin{array}{l}x^{2}=0 \\
\mathrm{p}>0.802\end{array}$ \\
\hline
\end{tabular}


Table 3 Gastric pH, bile acid concentrations, and Campylobacter like organism status

\begin{tabular}{|c|c|c|}
\hline Gastric pH & Bile a & id concentrations ( $\mathrm{mmol} / \mathrm{l})$ \\
\hline$\geqslant 4<4$ & $\geqslant 1$ & $<1$ \\
\hline $\begin{array}{l}\text { Negative } \\
\begin{array}{l}16 \quad 15 \\
\text { Positive } \\
7\end{array} 57 \text { p }<0.001\end{array}$ & $\begin{array}{r}11 \\
4\end{array}$ & $\left.\begin{array}{l}11 \\
46\end{array}\right\} \begin{array}{l}x^{2}=16.340 \\
\mathrm{p}<0.001\end{array}$ \\
\hline
\end{tabular}

modified score, reflecting the epithelial and vascular components of the inflammatory reaction, was also significantly higher in the Campylobacter negative group (data not shown).

No significant difference was found in the distribution of intestinal metaplasia with regard to overall Campylobacter like organism status, although bacteria were never present on focal areas of intestinal metaplasia in colonised biopsy specimens.

GASTRIC PH, BILE ACID CONCENTRATIONS, AND CAMPYLOBACTER LIKE ORGANISM STATUS

When the relation between Campylobacter like organism status and both fasting intragastric $\mathrm{pH}$ and bile acid concentrations was assessed (Table 3), there was a highly significant association between the absence of Campylobacter like organisms and both hypochlorhydria and high bile acid concentrations in the stomach. Of the 31 patients who were negative for Campylobacter like organisms, 16 had a gastric pH $\geqslant 4$, whereas only seven of the 64 positive patients were hypochlorhydric $(p<0.001)$. Likewise, of the 72 patients who had bile acid concentrations measured, 22 were negative, and 11 of these patients had bile acid concentrations $\geqslant 1 \mathrm{mmol} / \mathrm{l}$ whereas of the 50 who were Campylobacter positive, only four had abnormally high bile acid concentrations ( $p<0.001)$. Furthermore, intragastric $\mathrm{pH}$ (mean (SD)) was significantly higher in the negative group $4.3(2 \cdot 3)$ than in the positive group $2.5(1.5)(p=0.0015)$, as were bile acid concentrations $3.76(5.86) v 0.73(2.90)$ $(p=0.0039)$.

\section{Discussion}

This is the first study in which an attempt has been made to correlate Campylobacter like organism status with evidence of alkaline reflux into the stomach. In using histological evidence based on our contention that reflux gastritis can give rise to a distinctive histopathological picture, we should further emphasise that lesser degrees of foveolar hyperplasia, lamina propria oedema, and capillary congestion are common to all forms of gastritis. Thus we typically found "reflux" scores of 5-9 in biopsy specimens, which would be diagnosed as chronic superficial, or chronic atrophic gastritis. Only where the key features were severe and linked to a paucity of acute and chronic inflammatory cells, giving a score of 11-15 in our scheme, was the diagnosis of reflux gastritis indicated.

Using such histological criteria, it is of considerable interest that we found a highly significant difference in Campylobacter status between patients with reflux scores above and below 10. Conversely, the features that we believe constitute the histological picture of reflux gastritis were more severe in the negative than positive patients. The much lower incidence of Campylobacter like organisms in those patients, who by histological and other criteria are considered to have alkaline reflux into the stomach, supports the proposition that reflux represents a distinct aetiological factor and that the resultant gastritis is unrelated to Campylobacter infection. Our data, however, do not suggest that these aetiological agents are mutually exclusive; 12 of the 36 patients with high reflux scores (>10) had Campylobacter like organisms in at least one of their biopsy specimens. Nevertheless, corroborative evidence of reflux ( $\mathrm{pH} \geqslant 4$, bile acid concentrations $\geqslant 1$ ) was present in only four of the 12 patients, so the finding of high scores and Campylobacter like organisms might not represent coexistence of reflux and infection in all these cases, but might reflect the inability of an arbitrary scoring system to distinguish between those histological features which are most discriminatory in making a diagnosis of reflux. For instance, six of the 12 cases showed a mild or moderate increase in both acute and chronic inflammatory cells, findings that militate against a diagnosis of reflux gastritis.

We found highly significant correlations between the presence of Campylobacter like organisms and an increase in both acute and chronic inflammatory cells in the gastric mucosa. The mononuclear cell infiltrate in the lamina propria is the major diagnostic criterion in chronic superficial and atrophic gastritis. Therefore our findings are in agreement with previous studies that have shown a strong association between the presence of Campylobacter like organisms and the finding of "conventional" chronic gastritis in antral biopsies. $^{3-6}$ These studies, however, also claim that most biopsy specimens negative for Campylobacter like organisms are normal. We suspect that the reluctance to diagnose gastritis in the absence of an inflammatory cell infiltrate means that features of reflux gastritis have been previously overlooked, or regarded as part of the "normal" spectrum, and that a proportion of these so called normal biopsy specimens will show the changes of reflux gastritis.

Using fasting intragastric $\mathrm{pH}$ and bile acid concentrations as indices of alkaline reflux, we found a highly significant association between the absence of Campylobacter like organisms and both hypochlorhydria 
and increased bile acid concentrations in the stomach. These data provide further evidence, albeit indirect, that the aetiology of chronic gastritis developing under conditions of increased enterogastric reflux is likely to be largely related to the noxious effects of reflux on the gastric mucosa rather than to Campylobacter infection.

Our observations lead us to conclude that there are two principal categories of non-autoimmune chronic gastritis. The first is the currently accepted entity of "chronic gastritis" elucidated by Whitehead, ${ }^{10}$ in which the chronic inflammatory cell response predominates and activity is manifest by neutrophil polymorph infiltration. There are now good grounds for believing that this form is initiated or perpetuated by Campylobacter infection, or both.

The second major category, we suggest, is gastritis causally related to reflux of alkaline duodenal content into the stomach. This gives rise to an essentially "chemical" injury to the mucosa, which is chronic by virtue of constant repetition but which evokes a predominantly epithelial response where activity is reflected in the degree of compensatory foveolar hyperplasia. The mucosal response embraces other components of the vascular inflammatory reactionnamely vasodilatation, congestion, and interstitial oedema-but the inflammatory cell response seems to be unimportant.

With regard to other forms of gastritis, we have shown previously ${ }^{11}$ that there is a low incidence of gastric Campylobacter like organisms in cases of pernicious anaemia, and this finding is in keeping with the presumed autoimmune aetiology of the type A chronic gastritis found in such patients.

Another potentially important implication from our results is the suggestion that patients with peptic ulceration may revert from being positive for Campylobacter like organisms to being negative after gastric surgery. Of the 56 patients with peptic ulcer that we studied, $46(82 \%)$ were positive compared with only six of $23(26 \%)$ in the postoperative group. It is tempting to suggest that this radical change in Campylobacter like organism status may in some way be related to the effects of increased enterogastric reflux after surgery. Under normal conditions the presence of a $\mathrm{pH}$ gradient in the gastric mucus barrier creates near neutral conditions at the epithelial cell surface. The reflux of bile acids may disrupt the mucus barrier, thereby lowering $\mathrm{pH}$ at the cell surface and rendering the microenvironment unfavourable to colonisation by acid intolerant Campylobacter like organisms. Patients with peptic ulceration may thus undergo a transition from one predominant type of chronic gastritis to another - that is, from chronic superficial, or atrophic gastritis related to Campylobacter like organisms, to reflux gastritis after operation. Whether effective surgery to divert bile (closure of gastroenterostomy or construction of a Roux-en-Y loop) might cause the regression of the histological features we consider to be indicative of reflux gastritis or recolonisation of the gastric mucosa by Campylobacter like organisms, or both, remains to be assessed.

We thank Mr D Lunny for expert technical help and Mrs J Fearnley for typing the manuscript.

\section{References}

${ }^{1}$ Warren JR. Unidentified curved bacilli on gastric epithelium in active chronic gastritis. Lancet 1983;ii:1273.

${ }^{2}$ Rollason TP, Stone J, Rhodes JM. Spiral organisms in endoscopic biopsies of the human stomach. J Clin Pathol 1984;37:23-6.

${ }^{3}$ Langenberg ML, Tytgat GNJ, Schipper MEI, Rietra PJGM, Zanen HC. Campylobacter-like organisms in the stomach of patients and healthy individuals. Lancet 1984;i:1348.

${ }^{4}$ Burnett RA, Forrest JAH, Girdwood RWA, Fricker CR. ำ Campylobacter-like organisms in the stomach of patients and $\mathbb{D}$ healthy individuals. Lancet 1984; i:1349.

${ }^{5}$ McNulty CAM, Watson DM. Spiral bacteria of the gastric antrum. Lancet 1984;i:1068-9.

6 Jones DM, Lessells AM, Eldridge J. Campylobacter-like organisms on the gastric mucosa: culture, histological, and serological studies. J Clin Pathol 1984;37:1002-6.

${ }^{7}$ Steer HW. The gastro-duodenal epithelium in peptic ulceration. $J \overline{ }$ Pathol 1985;146:355-62.

${ }^{8}$ Marshall BJ, Armstrong JA, McGechie DB, Glancy RJ. Attempt to fulfil Koch's postulates for pyloric campylobacter. Med $J$ Aust 1985;142:436-9.

${ }^{9}$ Dixon MF, O'Connor HJ, Axon ATR, King RFGJ, Johnston D. Reflux gastritis-a distinct histopathological entity? $J$ Clin Pathol 1986;39:524-30.

${ }^{10}$ Whitehead R, Truelove SC, Gear MWL. The histological diagnosis $D$ of chronic gastritis in fibreoptic gastroscope biopsy specimens. $J$ 음 Clin Pathol 1972;25:1-11.

${ }^{11}$ O'Connor HJ, Axon ATR, Dixon MF. Campylobacter-like $\mathbb{O}$ organisms unusual in type A (pernicious anaemia) gastritis. Lancet 1984;ii:1091.

Requests for reprints to: Dr HJ O'Connor, Senior Medical Registrar, Selly Oak Hospital, Birmingham B29 6JD, England. 